\title{
Carboxydocella manganica sp. nov., a thermophilic, dissimilatory Mn(IV)- and Fe(III)-reducing bacterium from a Kamchatka hot spring
}

\author{
G. B. Slobodkina, ${ }^{1}$ A. N. Panteleeva, ${ }^{2}$ T. G. Sokolova, ${ }^{1}$ \\ E. A. Bonch-Osmolovskaya ${ }^{1}$ and A. I. Slobodkin ${ }^{1}$ \\ ${ }^{1}$ Winogradsky Institute of Microbiology, Russian Academy of Sciences, \\ Prospect 60-letiya Oktyabrya 7/2, 117312 Moscow, Russia \\ ${ }^{2}$ Bioengineering Center, Russian Academy of Sciences, Prospect 60-letiya Oktyabrya 7/1, \\ 117312 Moscow, Russia
}

Correspondence

G. B. Slobodkina

gslobodkina@mail.ru

\begin{abstract}
A thermophilic, anaerobic, dissimilatory Mn(IV)- and Fe(III)-reducing bacterium (strain SLM $61^{\top}$ ) was isolated from a terrestrial hot spring on the Kamchatka peninsula. The cells were straight rods, $0.5-0.6 \mu \mathrm{m}$ in diameter and 1.0-6.0 $\mu \mathrm{m}$ long, and exhibited tumbling motility by means of peritrichous flagellation. The strain grew at $26-70{ }^{\circ} \mathrm{C}$, with an optimum at $58-60{ }^{\circ} \mathrm{C}$, and at $\mathrm{pH}$ 5.5-8.0, with an optimum at $\mathrm{pH}$ 6.5. Growth of SLM $61^{\top}$ was observed at $0-2.0 \%(\mathrm{w} / \mathrm{v})$ $\mathrm{NaCl}$, with an optimum at $0.5 \%(\mathrm{w} / \mathrm{v})$. The generation time under optimal growth conditions was 40 min. Strain SLM $61^{\top}$ grew and reduced Mn(IV), Fe(III) or nitrate with a number of organic acids and complex proteinaceous compounds as electron donors. It was capable of chemolithoautotrophic growth using molecular hydrogen as an electron donor, Fe(III) but not $\mathrm{Mn}(\mathrm{IV})$ or nitrate as an electron acceptor and $\mathrm{CO}_{2}$ as a carbon source. It also was able to ferment pyruvate, yeast extract, glucose, fructose, sucrose and maltose. The $G+C$ content of DNA of strain SLM $61^{\top}$ was 50.9 mol\%. 16S rRNA gene sequence analysis revealed that the closest relative of the isolated organism was Carboxydocella thermautotrophica $41^{\top}$ (96.9\% similarity). On the basis of its physiological properties and phylogenetic analyses, the isolate is considered to represent a novel species, for which the name Carboxydocella manganica sp. nov. is proposed. The type strain is SLM $61^{\top}\left(=\mathrm{DSM} 23132^{\top}=\mathrm{VKM} \mathrm{B}-2609^{\top}\right)$. C. manganica is the first described representative of the genus Carboxydocella that possesses the ability to reduce metals and does not utilize $\mathrm{CO}$.
\end{abstract}

Metal-reducing micro-organisms play important roles in the cycling of carbon and metals in various anaerobic ecosystems, including thermal environments. Dissimilatory Fe(III)and $\mathrm{Mn}(\mathrm{IV})$-reducing micro-organisms have been found in a variety of thermal biotopes, including continental hot springs, a deep terrestrial subsurface, submarine petroleum reservoirs, deep-sea hydrothermal vents and anthropogenic systems (Lovley et al., 2004; Slobodkin, 2005). Dissimilatory manganese reduction by thermophilic prokaryotes is much less well studied than iron reduction. Of 43 described species of $\mathrm{Fe}(\mathrm{III})$-reducing thermophiles belonging to different phylogenetic groups of the Bacteria and Archaea, the capacity for $\mathrm{Mn}(\mathrm{IV})$ reduction has been reported for six species

Abbreviations: AODS, 9,10-anthraquinone 2,6-disulfonate; CFA, cellular fatty acid.

The GenBank/EMBL/DDBJ accession number for the 16S rRNA gene sequence of strain SLM $61^{\top}$ is GU584133.

A supplementary table is available with the online version of this paper.
(Slobodkin, 2005). Only two micro-organisms, Bacillus infernus (Boone et al., 1995) and Deferribacter thermophilus (Greene et al., 1997), were first isolated using $\mathrm{Mn}(\mathrm{IV})$ as an electron acceptor. In this article, we report the isolation and characterization of a novel anaerobic, thermophilic, Mn(IV)and $\mathrm{Fe}$ (III)-reducing micro-organism from a hydrothermal spring on the Kamchatka peninsula.

Strain SLM $61^{\mathrm{T}}$ was isolated from a sample of sediment collected from a hot spring at the 'Trostnikovyi' field, Uzon Caldera, Kamchatka, Russia. The conditions at the sampling site were $60{ }^{\circ} \mathrm{C}, \mathrm{pH} 6.2, E_{\mathrm{h}}-400 \mathrm{mV}$. Samples were taken anaerobically in tightly stoppered bottles and transported to the laboratory. Enrichment cultures were initiated by inoculation of $10 \%(\mathrm{w} / \mathrm{v})$ of the sample into anaerobically prepared, bicarbonate-buffered, sterile $\left(135^{\circ} \mathrm{C}, 1 \mathrm{~h}\right)$ liquid medium with lactate $(14 \mathrm{mM})$ as an electron donor and manganese(IV) oxide $\left(25 \mathrm{mmol} \mathrm{l}^{-1}\right)$ as an electron acceptor. Medium composition and preparation techniques were described previously (Slobodkin et al., 1999). $\mathrm{MnO}_{2}$ 
(birnessite) was prepared by $\mathrm{O}_{2}$ (air) oxidation of $\mathrm{MnCl}_{2}$ in alkali medium (Feng et al., 2004). A pure culture was obtained from an enrichment positive for $\mathrm{Mn}(\mathrm{IV})$ reduction by serial dilutions in the same medium followed by the selection of well-separated colonies that had developed in anaerobic agar blocks (1.5\% agar in growth medium). Since $\mathrm{MnO}_{2}$ is a black, insoluble compound, it is inconvenient for colonies to be obtained in solidified medium, and it was replaced by $\mathrm{KNO}_{3}$. Light-brown, irregular-shaped colonies, $0.5-1.0 \mathrm{~mm}$ in diameter, appeared after 3 days of incubation at $60{ }^{\circ} \mathrm{C}$. Individual colonies were checked for manganese-reducing ability by transferring them to liquid medium with $\mathrm{MnO}_{2}$ and, for positive cultures, the process of obtaining colonies was repeated two more times. Finally, a single colony that had developed in the highest agar block dilution $\left(10^{-6}\right)$ and possessed $\mathrm{Mn}(\mathrm{IV})$-reducing ability was designated strain SLM $61^{\mathrm{T}}$ and used for further studies.

Physiological studies on substrate and electron acceptor utilization, temperature, $\mathrm{pH}$ and salinity ranges for growth, light and electron microscopy, analytical techniques, DNA extraction and determination of $\mathrm{G}+\mathrm{C}$ content were performed as described previously (Slobodkin et al., 1999). Manganese $\left(\mathrm{Mn}^{2+}\right)$ contents were determined by the formaldoxime method (Goto et al., 1962). Ammonium and nitrite were determined by HPLC with a conductivity detector (Aquilon C1P column, $4 \mathrm{mM} \mathrm{HNO}_{3}$, for ammonium and Aquilon A1.2 column, $3.5 \mathrm{mM}$ carbonate buffer, for nitrite). Cellular fatty acid (CFA) profiles were determined by GC-MS as methyl ester derivatives prepared from $5 \mathrm{mg}$ dry cell material (Sasser, 1990). CFA content was determined as percentages of total ion current peak area. The 16S rRNA gene was selectively amplified from genomic DNA by PCR using primers 11F and 1492R (Lane, 1991). The PCR was carried out in $50 \mu$ reaction mixture containing $50 \mathrm{ng}$ DNA template, 5 pmol (each) primers, $12.5 \mathrm{nmol}$ (each) dNTPs and $3 \mathrm{U}$ Taq DNA polymerase (Fermentas) in Taq DNA polymerase reaction buffer (Fermentas). Temperature cycling was done by using the following program: first cycle of $9 \mathrm{~min}$ at $94{ }^{\circ} \mathrm{C}, 1 \mathrm{~min}$ at $55{ }^{\circ} \mathrm{C}$ and $2 \mathrm{~min}$ at $72{ }^{\circ} \mathrm{C}$, followed by 30 amplification cycles of $1 \mathrm{~min}$ at $94{ }^{\circ} \mathrm{C}, 1 \mathrm{~min}$ at $55^{\circ} \mathrm{C}$ and $1 \mathrm{~min}$ at $72{ }^{\circ} \mathrm{C}$. A final extension step was carried out at $72{ }^{\circ} \mathrm{C}$ for $7 \mathrm{~min}$. PCR products were purified using the Wizard PCR Preps kit (Promega) as recommended by the manufacturer. The $16 \mathrm{~S}$ rRNA gene was sequenced in both directions with the use of Big Dye Terminator version 3.1 (Applied Biosystems), as described in the manufacturer's instructions, using an ABI PRISM 3730 sequencer (Applied Biosystems). Sequences were assembled and checked for accuracy manually using the alignment editor BioEdit version 5.0.9 (Hall, 1999). The full-length $16 \mathrm{~S}$ rRNA gene sequence was compared with other sequences in GenBank (Benson et al., 1999) using BLAST (Altschul et al., 1997) to identify the closest relatives. Alignment with a representative set of other 16S rRNA gene sequences in GenBank was carried out using the CLUSTAL w program provided by the phylogenetic analysis package MEGA version 4 (Tamura et al., 2007) and then adjusted manually. Pairwise similarity values were calculated by means of EzTaxon (Chun et al., 2007). A phylogenetic dendrogram was reconstructed by the neighbour-joining method (Saitou \& Nei, 1987) with the maximum composite likelihood model (Tamura et al., 2004) using MEGA version 4. Carboxydocella thermautotrophica DSM $12356^{\mathrm{T}}$ and C. sporoproducens DSM $16521^{\mathrm{T}}$ were obtained from the Deutsche Sammlung von Mikroorganismen und Zellkulturen (Braunschweig, Germany) and used as reference strains.

Cells of strain SLM $61^{\mathrm{T}}$ were straight rods, $0.5-0.6 \mu \mathrm{m}$ in diameter and 1.0-6.0 $\mu \mathrm{m}$ long. The cells occurred singly or in pairs and were motile by means of peritrichous flagellation. Spores were not observed. Ultrathin sectioning of strain SLM $61^{\mathrm{T}}$ revealed the presence of a distinct electron-dense material typical of the peptidoglycan layer of a Gram-positive-type cell wall.

The temperature range for growth of strain SLM $61^{\mathrm{T}}$ was $26-70{ }^{\circ} \mathrm{C}$, with an optimum at $58-60{ }^{\circ} \mathrm{C}$. No growth was detected at or above $71{ }^{\circ} \mathrm{C}$ or at $25{ }^{\circ} \mathrm{C}$ or below after incubation for 3 weeks. The $\mathrm{pH}$ range for growth was 5.58.0 , with an optimum at $\mathrm{pH} 6.5$. No growth was noted at or below $\mathrm{pH} 5.0$ or at or above $\mathrm{pH}$ 8.5. Growth of strain SLM $61^{\mathrm{T}}$ was observed at $0-2.0 \%(\mathrm{w} / \mathrm{v}) \mathrm{NaCl}$ with an optimum at $0.5 \%(\mathrm{w} / \mathrm{v})$; no growth was evident at or above $2.5 \%(\mathrm{w} / \mathrm{v})$ $\mathrm{NaCl}$. Yeast extract was not required for growth, but addition of $0.20 \mathrm{~g}$ yeast extract $\mathrm{l}^{-1}$ increased final cell yield 10 - to 15 -fold. Potential electron acceptors were tested with sodium lactate $(14 \mathrm{mM})$ as an energy source in the presence of $0.20 \mathrm{~g}$ yeast extract $\mathrm{l}^{-1}$. Manganese(IV) oxide $(25 \mathrm{mmol}$ $\mathrm{MnO}_{2} \mathrm{l}^{-1}$ ), poorly crystalline iron(III) oxide (ferrihydrite) [90 mmol $\mathrm{Fe}(\mathrm{III}) \mathrm{l}^{-1}$ ], iron(III) citrate $(10 \mathrm{mM})$ and potassium nitrate $(10 \mathrm{mM})$ were used as electron acceptors for growth of strain SLM $61^{\mathrm{T}}$. Sulfate $(14 \mathrm{mM})$, elemental sulfur $\left(10 \mathrm{~g} \mathrm{l}^{-1}\right)$, thiosulfate, 9,10-anthraquinone 2,6disulfonate (AQDS), fumarate $(20 \mathrm{mM}$ each) and oxygen (3 or $20 \%, v / v$, in the gas phase) were not reduced and did not support growth. During Mn(IV) reduction, black insoluble $\mathrm{MnO}_{2}$ turned to a light-brown precipitate containing 5-7 $\mathrm{mM} \mathrm{Mn}(\mathrm{II})$. Ferrihydrite was reduced to a black magnetic precipitate with an $\mathrm{Fe}$ (II) content of 25$30 \mathrm{mM}$. No changes in colour or volume of precipitate were observed in uninoculated controls with $\mathrm{Mn}$ (IV) and $\mathrm{Fe}(\mathrm{III})$ incubated under the same conditions. Nitrate was reduced to ammonium. Lactate was oxidized incompletely to acetate. Strain SLM $61^{\mathrm{T}}$ was able to grow and reduce Fe(III), $\mathrm{Mn}$ (IV) and nitrate with lactate, pyruvate (14 $\mathrm{mM}$ each), formate, butyrate, succinate ( $20 \mathrm{mM}$ each), yeast extract, peptone, tryptone $\left(2.5 \mathrm{~g} \mathrm{l}^{-1}\right.$ each $)$ and $\mathrm{H}_{2} / \mathrm{CO}_{2}(80 / 20 \mathrm{v} / \mathrm{v})$ as electron donors. Strain SLM $61^{\mathrm{T}}$ could grow chemolithoautotrophically in the absence of yeast extract, using molecular hydrogen as an electron donor and ferrihydrite [but not $\mathrm{Mn}(\mathrm{IV})$ or nitrate] as an electron acceptor and bicarbonate/ $\mathrm{CO}_{2}$ as a carbon source. It also was able to grow without electron acceptors by fermentation of pyruvate, glucose, fructose, sucrose, maltose (15 $\mathrm{mM}$ each) and yeast extract $\left(2.5 \mathrm{~g} \mathrm{l}^{-1}\right)$. The main product of glucose fermentation (15 mM initial concentration) was acetate $(28-30 \mathrm{mM})$, 
with trace amounts $(<1.0 \mathrm{mM})$ of ethanol, formate, lactate and succinate; no molecular hydrogen was produced. The generation time under optimal growth conditions on pyruvate was $40 \mathrm{~min}$. Isolate SLM $61^{\mathrm{T}}$ did not utilize acetate $(10 \mathrm{mM})$, propionate, fumarate, maleinate, methanol, ethanol or glycerol $(20 \mathrm{mM}$ each) with iron(III) citrate $(5 \mathrm{mM})$, manganese(IV) oxide $\left(25 \mathrm{mmol} \mathrm{l}^{-1}\right)$ or potassium nitrate $(10 \mathrm{mM})$ as electron acceptor. No growth was observed on peptone or tryptone $\left(2.5 \mathrm{~g} \mathrm{l}^{-1}\right.$ each $)$ without an electron acceptor. Xylose, L-arabinose, lactose, galactose, cellobiose (15 mM each), starch $\left(2.5 \mathrm{~g} \mathrm{l}^{-1}\right)$ and citrate $(10 \mathrm{mM})$ were not utilized with or without an electron acceptor. No growth or electron acceptor reduction was observed during cultivation on carbon monoxide $(5,15,45$ or $100 \%$ CO in gas phase) with ferrihydrite [ $90 \mathrm{mmol}$ $\mathrm{Fe}$ (III) $\mathrm{l}^{-1}$, manganese(IV) oxide $\left(25 \mathrm{mmol} \mathrm{l}^{-1}\right)$ or $\mathrm{KNO}_{3}$ $(10 \mathrm{mM})$ or without an acceptor added. Penicillin, ampicillin, streptomycin, novobiocin, kanamycin and neomycin (each at $100 \mu \mathrm{g} \mathrm{ml}^{-1}$ ) inhibited growth of strain SLM $61^{\mathrm{T}}$. The fatty acids comprised a mixture of straight-chain and iso- and anteiso-branched fatty acids (Table S1, available in IJSEM Online). $\mathrm{C}_{16: 0}$ predominated among the fatty acids $(31.38 \%)$; iso- $\mathrm{C}_{15: 0}, \mathrm{C}_{16: 1} \omega 7 c$, iso- $\mathrm{C}_{17: 0}$, iso- $\mathrm{C}_{17: 1} \omega 8$, $\mathrm{C}_{18: 0}, \mathrm{C}_{18: 1} \omega 7(5.23-9.95 \%)$ and $\mathrm{C}_{14: 0}, \mathrm{C}_{15: 0}$, iso- $\mathrm{C}_{16: 0}$, $\mathrm{C}_{16: 1} \omega 9$, iso- $\mathrm{C}_{17: 1} \omega 6 c$, anteiso- $\mathrm{C}_{17: 0}, \mathrm{C}_{17: 0}$ and $\mathrm{C}_{18: 1} \omega 9$ (1.10-2.75\%) were also present.

The $\mathrm{G}+\mathrm{C}$ content of the genomic DNA of strain SLM $61^{\mathrm{T}}$ was $50.9 \mathrm{~mol} \%\left(T_{\mathrm{m}}\right)$. A comparison of $1522 \mathrm{nt}$ of the $16 \mathrm{~S}$ rRNA gene sequence of strain SLM $61^{\mathrm{T}}$ with those available in the GenBank database showed that strain SLM $61^{\mathrm{T}}$ belonged to the genus Carboxydocella (Fig. 1). The $16 \mathrm{~S}$ rRNA gene sequence of the new isolate had the highest pairwise similarity to that of C. thermautotrophica $41^{\mathrm{T}}$ (96.9\%). The level of $16 \mathrm{~S}$ rRNA gene sequence similarity to C. sporoproducens $\operatorname{Kar}^{\mathrm{T}}$ was $96.7 \%$. Trees reconstructed by using the maximum-likelihood and maximum-parsimony algorithms displayed the same topology (not shown). Transversion analysis (Woese et al., 1991) did not affect the phylogenetic position of the novel strain.

The new isolate described in this report represents a thermophilic micro-organism capable of reduction of $\mathrm{Mn}(\mathrm{IV})$ and $\mathrm{Fe}(\mathrm{III})$ and, phylogenetically, it is closest to members of the genus Carboxydocella. At the time of writing, the genus Carboxydocella consists of two species with validly published names, $C$. thermautotrophica Sokolova et al. 2002 (type species) and C. sporoproducens Slepova et al. 2006, and the novel isolate shares many phenotypic features with them. All members of the genus Carboxydocella display motile, rod-shaped cells and grow under anaerobic conditions, have very similar ranges of growth temperature and $\mathrm{pH}$ and were isolated from hot springs in Kamchatka. However, strain SLM $61^{\mathrm{T}}$ displays a number of significant differences (Table 1). The most significant distinction of strain SLM $61^{\mathrm{T}}$ from the other representatives of the genus Carboxydocella is its inability to grow on carbon monoxide, not only at $100 \% \mathrm{CO}$ in the gas phase but also at lower concentrations. It was reported

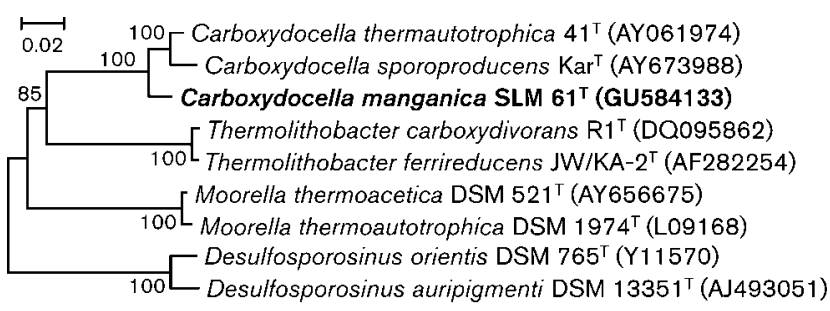

Fig. 1. Phylogenetic tree based on $16 \mathrm{~S}$ rRNA gene sequences indicating the position of strain SLM $61^{\top}$. The tree was reconstructed using the neighbour-joining algorithm. GenBank accession numbers are given in parentheses. Bar, 2 substitutions per 100 nucleotide positions. Only bootstrap values greater $70 \%$ are indicated.

previously that nitrate inhibits growth of C. sporoproducens. In our study, we found that C. thermautotrophica DSM $12326^{\mathrm{T}}$ could also not grow and reduce nitrate with lactate or $\mathrm{CO}$ as electron donor. Unlike other members of the genus Carboxydocella, strain SLM $61^{\mathrm{T}}$ is able to use nitrate as an electron acceptor. It utilizes a wider spectrum of substrates, including hydrogen, mono- and disaccharides, organic acids and complex proteinaceous compounds. We performed additional studies on sugar utilization by $C$. thermautotrophica DSM $12326^{\mathrm{T}}$ in the presence of yeast extract in the culture medium used for cultivation of strain SLM $61^{\mathrm{T}}$ and confirmed its inability to consume carbohydrates. Strain SLM $61^{\mathrm{T}}$ was enriched on Mn(IV) as electron acceptor and possesses the capacity for $\mathrm{Mn}(\mathrm{IV})$ and $\mathrm{Fe}(\mathrm{III})$ reduction. This ability was not shown previously for micro-organisms belonging to the genus Carboxydocella. In our study, we found that C. thermautotrophica DSM $12326^{\mathrm{T}}$ could not reduce $\mathrm{Mn}(\mathrm{IV})$ or $\mathrm{Fe}(\mathrm{III})$ with lactate, molecular hydrogen or CO as electron donor. In contrast, C. sporoproducens DSM $16521^{\mathrm{T}}$ could grow and reduce $\mathrm{Mn}(\mathrm{IV})$ and $\mathrm{Fe}(\mathrm{III})$ with lactate as electron donor, at least in three sequential transfers. So, metal-reducing ability is not unique to the new isolate, but is inherent to the genus Carboxydocella. The strains also had some differences in G+C content of DNA and CFA profiles. The major fatty acid for all strains was $\mathrm{C}_{16: 0}$; the second most abundant fatty acid for C. sporoproducens DSM $16521^{\mathrm{T}}$ and C. thermautotrophica DSM $12326^{\mathrm{T}}$ was the saturated straight-chain acid $\mathrm{C}_{18: 0}$, whereas for strain SLM61 ${ }^{\mathrm{T}}$, the next most abundant fatty acids were $\mathrm{C}_{16: 1} \omega 7 c$ and iso- $\mathrm{C}_{17: 0}$ (Table 1). On the basis of the phylogenetic position and phenotypic and physiological properties, we propose that strain SLM $61^{\mathrm{T}}$ represents a novel species, Carboxydocella manganica sp. nov.

\section{Description of Carboxydocella manganica sp. nov.}

Carboxydocella manganica (man.ga' ni.ca. N.L. fem. adj. manganica pertaining to manganese).

Cells are straight, motile rods, $0.5-0.6 \mu \mathrm{m}$ in diameter and $1.0-6.0 \mu \mathrm{m}$ long. Spores are not observed. The cell wall is of the Gram-positive type. Cells form light-brown, 
Table 1. Characteristics that differentiate strain SLM $61^{\top}$ from the type strains of Carboxydocella species

Strains: 1, C. manganica sp. nov. SLM 61 ${ }^{\mathrm{T}}$; 2, C. sporoproducens DSM $16521^{\mathrm{T}}$; 3, C. thermautotrophica DSM $12326^{\mathrm{T}}$. Data were obtained in this study.

\begin{tabular}{|c|c|c|c|}
\hline Characteristic & 1 & 2 & 3 \\
\hline CO utilization & - & + & + \\
\hline \multicolumn{4}{|l|}{ Electron acceptors } \\
\hline $\operatorname{Mn}(\mathrm{IV})$ & + & + & - \\
\hline $\mathrm{Fe}(\mathrm{III})$ & + & + & - \\
\hline $\mathrm{KNO}_{3}$ & + & - & - \\
\hline \multicolumn{4}{|l|}{ Electron donors } \\
\hline Yeast extract & + & + & - \\
\hline Peptone, tryptone & + & - & - \\
\hline Molecular hydrogen & + & - & - \\
\hline Formate & + & - & - \\
\hline Lactate & + & + & - \\
\hline Pyruvate & + & + & - \\
\hline Glucose, fructose, maltose & + & - & - \\
\hline Sucrose & + & + & - \\
\hline $\begin{array}{l}\text { Main CFAs (\% of total CFA } \\
\text { content) }\end{array}$ & $\begin{array}{c}\mathrm{C}_{16: 0}(31.38), \mathrm{C}_{16: 1} \omega 7 c \\
(9.95) \\
\text { iso- } \mathrm{C}_{17: 0}(9.90)\end{array}$ & $\begin{array}{c}\mathrm{C}_{16: 0}(35.84), \mathrm{C}_{18: 0} \\
(16.35)\end{array}$ & $\begin{array}{c}\mathrm{C}_{16: 0}(38.58), \mathrm{C}_{18: 0} \\
(15.47)\end{array}$ \\
\hline DNA G $+\mathrm{C}$ content $(\mathrm{mol} \%)$ & 50.9 & 49.5 & 46.0 \\
\hline
\end{tabular}

irregular-shaped colonies $(0.5-1.0 \mathrm{~mm}$ in diameter) in anaerobic agar blocks. The temperature range for growth is $26-70{ }^{\circ} \mathrm{C}$, with an optimum at $58-60{ }^{\circ} \mathrm{C}$. The $\mathrm{pH}$ range for growth is $5.5-8.0$, with an optimum at $\mathrm{pH}$ 6.5. Growth occurs at $0-2.0 \%(\mathrm{w} / \mathrm{v}) \mathrm{NaCl}$, with an optimum at $0.5 \%$ (w/v). Anaerobic. Reduces insoluble oxides of $\mathrm{Mn}(\mathrm{IV})$ and $\mathrm{Fe}(\mathrm{III})$. Utilizes peptone, tryptone, yeast extract, molecular hydrogen, formate, butyrate, lactate, pyruvate and succinate with $\mathrm{Mn}(\mathrm{IV}), \mathrm{Fe}(\mathrm{III})$ or nitrate as an electron acceptor. Lactate is oxidized incompletely to acetate. Capable of chemolithoautotrophic growth using molecular hydrogen as an electron donor, $\mathrm{Fe}(\mathrm{III})$ as an electron acceptor and $\mathrm{CO}_{2}$ as a carbon source. Ferments pyruvate, yeast extract, glucose, fructose, sucrose and maltose. The main product of glucose fermentation is acetate. Does not utilize acetate, propionate, fumarate, maleinate, methanol, ethanol, glycerol, xylose, L-arabinose, lactose, galactose, cellobiose, starch or citrate, with or without electron acceptor. Sulfate, elemental sulfur, thiosulfate, AQDS, fumarate and oxygen are not reduced and do not support growth. No growth on carbon monoxide with or without electron acceptor. Penicillin, ampicillin, streptomycin, novobiocin, kanamycin and neomycin inhibit growth at $100 \mu \mathrm{l} \mathrm{ml}{ }^{-1}$. The major fatty acid is $\mathrm{C}_{16: 0}$. The $\mathrm{G}+\mathrm{C}$ content of DNA of the type strain is $50.9 \mathrm{~mol} \%\left(T_{\mathrm{m}}\right)$.

The type strain, SLM $61^{\mathrm{T}}$ (=DSM $23132^{\mathrm{T}}=\mathrm{VKM} \mathrm{B}-2609^{\mathrm{T}}$ ), was isolated from a terrestrial hot spring at Kamchatka, Russia.

\section{Acknowledgements}

This work was supported by the Russian Foundation for Basic Research (grant 09-04-00251-a) from and by the Programs 'Molecular and cell biology' and 'The origin and evolution of the biosphere' of the Russian Academy of Sciences.

\section{References}

Altschul, S. F., Madden, T. L., Schäffer, A. A., Zhang, J., Zhang, Z., Miller, W. \& Lipman, D. J. (1997). Gapped BLAST and PSI-BLAST: a new generation of protein database search programs. Nucleic Acids Res 25, 3389-3402.

Benson, D. A., Boguski, M. S., Lipman, D. J., Ostell, J., Ouellette, B. F., Rapp, B. A. \& Wheeler, D. L. (1999). GenBank. Nucleic Acids Res 27, 12-17.

Boone, D. R., Liu, Y., Zhao, Z.-J., Balkwill, D. L., Drake, G. R., Stevens, T. O. \& Aldrich, H. C. (1995). Bacillus infernus sp. nov., an Fe(III)- and $\mathrm{Mn}(\mathrm{IV})$-reducing anaerobe from the deep terrestrial subsurface. Int $J$ Syst Bacteriol 45, 441-448.

Chun, J., Lee, J.-H., Jung, Y., Kim, M., Kim, S., Kim, B. K. \& Lim, Y. W. (2007). EzTaxon: a web-based tool for the identification of prokaryotes based on $16 \mathrm{~S}$ ribosomal RNA gene sequences. Int J Syst Evol Microbiol 57, 2259-2261.

Feng, X. H., Liu, F., Tan, W. F. \& Liu, X. W. (2004). Synthesis of birnessite from the oxidation of $\mathrm{Mn}^{2+}$ by $\mathrm{O}_{2}$ in alkali medium: effects of synthesis conditions. Clays Clay Miner 52, 240-250.

Goto, K., Komatsu, T. \& Furukawa, T. (1962). Rapid colorimetric determination of manganese in waters containing iron: a modification of the formaldoxime method. Anal Chim Acta 27, 331-334.

Greene, A. C., Patel, B. K. C. \& Sheehy, A. J. (1997). Deferribacter thermophilus gen. nov., sp. nov., a novel thermophilic manganeseand iron-reducing bacterium isolated from a petroleum reservoir. Int J Syst Bacteriol 47, 505-509.

Hall, T. A. (1999). BioEdit: a user-friendly biological sequence alignment editor and analysis program for Windows 95/98/NT. Nucleic Acids Symp Ser 41, 95-98.

Lane, D. J. (1991). 16S/23S rRNA sequencing. In Nucleic Acid Techniques in Bacterial Systematics, pp. 115-175. Edited by E. Stackebrandt \& M. Goodfellow. Chichester: Wiley. 
Lovley, D. R., Holmes, D. E. \& Nevin, K. P. (2004). Dissimilatory $\mathrm{Fe}(\mathrm{III})$ and $\mathrm{Mn}(\mathrm{IV})$ reduction. Adv Microb Physiol 49, 219-286.

Saitou, N. \& Nei, M. (1987). The neighbor-joining method: a new method for reconstructing phylogenetic trees. Mol Biol Evol 4, 406-425.

Sasser, M. (1990). Identification of bacteria by gas chromatography of cellular fatty acids, MIDI Technical Note 101. Newark, DE: MIDI Inc.

Slepova, T. V., Sokolova, T. G., Lysenko, A. M., Tourova, T. P., Kolganova, T. V., Kamzolkina, O. V., Karpov, G. A. \& BonchOsmolovskaya, E. A. (2006). Carboxydocella sporoproducens sp. nov., a novel anaerobic $\mathrm{CO}$-utilizing/ $\mathrm{H}_{2}$-producing thermophilic bacterium from a Kamchatka hot spring. Int J Syst Evol Microbiol 56, 797-800.

Slobodkin, A. I. (2005). Thermophilic microbial metal reduction. Microbiology (English translation of Mikrobiologiia) 74, 501-514.

Slobodkin, A. I., Tourova, T. P., Kuznetsov, B. B., Kostrikina, N. A., Chernyh, N. A. \& Bonch-Osmolovskaya, E. A. (1999).

Thermoanaerobacter siderophilus sp. nov., a novel dissimilatory
$\mathrm{Fe}(\mathrm{III})$-reducing, anaerobic, thermophilic bacterium. Int $J$ Syst Bacteriol 49, 1471-1478.

Sokolova, T. G., Kostrikina, N. A., Chernyh, N. A., Tourova, T. P., Kolganova, T. V. \& Bonch-Osmolovskaya, E. A. (2002). Carboxydocella thermautotrophica gen. nov., sp. nov., a novel anaerobic, CO-utilizing thermophile from a Kamchatkan hot spring. Int J Syst Evol Microbiol 52, 1961-1967.

Tamura, K., Nei, M. \& Kumar, S. (2004). Prospects for inferring very large phylogenies by using the neighbor-joining method. Proc Natl Acad Sci U S A 101, 11030-11035.

Tamura, K., Dudley, J., Nei, M. \& Kumar, S. (2007). MEGA4: molecular evolutionary genetics analysis (MEGA) software version 4.0. Mol Biol Evol 24, 1596-1599.

Woese, C. R., Achenbach, L., Rouviere, P. \& Mandelco, L. (1991). Archaeal phylogeny: reexamination of the phylogenetic position of Archaeoglobus fulgidus in light of certain composition-induced artifacts. Syst Appl Microbiol 14, 364-371. 